\title{
Ex-situ Morphological and Morphometric Studies of the Testis In the West African Dwarf Buck Goat
}

\author{
Lukman Oladimeji Raji ${ }^{*}$, Oluwatoyin Oluwasola Ajala² \\ ${ }^{l}$ Department of Theriogenology and Production, University of Ilorin, Ilorin, Kwara State, Nigeria. \\ ${ }^{2}$ Department of Surgery and Reproduction, University of Ibadan, Ibadan, Oyo State, Nigeria.
}

\section{A R T I C LE I N F O}

Article history:

Received 14 August 2015

Accepted 26 October 2015

Available online, ISSN: 2148-127X

Keywords:

Ex-situ

Morphology

Morphometry

Characteristics

West African Dwarf Buck

${ }^{*}$ Corresponding Author:

E-mail: raji.lo@unilorin.edu.ng

\section{A B S T R A C T}

This study was carried out to document ex-situ morphological and morphometric characteristics of the testis in the West African Dwarf (WAD) buck goat. For this aim, 24 post pubertal WAD buck testes were collected at the Ipata Abattoir in Ilorin, Kwara state, Nigeria. Gross morphologic results revealed that WAD testis was ellipsoidal in shape with 2 borders (free and attached), margins (medial and lateral) and similar surfaces (ventral and dorsal). The surfaces were covered by an outer tunica vaginalis and a deep tunica albuginea. Histomorphology showed the testis comprised mostly of rounded and some irregularly shaped seminiferous tubules (ST). Each ST was lined by a basement membrane and a layer of germinal epithelium with lumen filled with spermatozoa surrounded by an adluminal space. Gross morphometric results showed that there were no significant differences in the weight, length, width and height of the right and left testis. Also in the volumes of testes obtained by water displacement method and using the prolate ellipsoid formula. There was a strong correlation between the weights and volumes of testes obtained using these methods. There were significant differences between the volumes of testes obtained by using the prolate spheroid and Lambert formulae, when compared with those obtained by water displacement method respectively. But there was no significant difference in testicular volume obtained by the prolate ellipsoid formula and the water displacement method. Histomorphometric results revealed no significant differences in the seminiferous tubular diameter, seminiferous luminal diameter and germinal epithelia height of the right and left testes respectively. The morphological and morphometric data highlighted in this study would be useful in comparative regional anatomy and researches on the testis of these valuable breed of goats.

\section{Introduction}

The testis is the main reproductive organ of the West African Dwarf buck (WAD) goat (being a typical mammalian species). It is the site of production for spermatozoa, testosterone and other sex hormones. The spermatozoa are required for fertilization of the ova from the WAD doe for conception, pregnancy and subsequent production of kids. Testosterone is important for spermatogenesis, development of the testes, prostate and secondary sexual characteristics of the WAD bucks (Daramola et al, 2007; Ugwu, 2009). Hence, particular attention is often given to the testis during breeding soundness examination (BSE). Its consistency, shape and especially the size (in terms of scrotal circumference) are usually examined during this exercise (Memon et al, 2007; Ridler et al, 2012).

In-situ, the testes of WAD bucks are paired except in disease conditions such as cryptorchidism where only one testis descends into the scrotum (Igbokwe et al, 2009;
Ozegbe, 2012). They are usually ovoid or long ovoid, undivided or split, symmetrical or asymmetrical (Ugwu, 2009; Okere et al, 2011). However, research shows that there is only a dart of information on the testes of WAD bucks ex-situ. As regards this, testicular morphological and morphometric data are very scarce. Morphology is meant to provide basic information about the normal testicular architecture; while morphometry estimates the dimensions, amount of testicular tissues and activities (Gofur, 2015). Hence, the reproductive anatomy and functions of the testes of these valuable sources of protein animals will be better understood (Devendra, 1999). These would constitute basic reproductive anatomy diagnostic and research tools for these animals. Therefore, this study was conducted to investigate and document the ex-situ morphological and morphometric characteristics of the testis in the WAD buck goat. 


\section{Materials and Methods}

Animals and Sample Collection

For this study, twenty four whole testes were harvested from the scrota of WAD bucks of average age of 2 years, body weight of $11.5 \mathrm{~kg}$ and scrotal circumference (SC) of $17.5 \mathrm{~cm}$, immediately after slaughter at the Ipata Abattoir in Ilorin, Kwara state, Nigeria. The scrota were washed with soap, cleaned with warm water and disinfected with iodine. A size 4 scalpel blade was used to make a skin incision from the dorsomedial aspect of the scrotum. This was reflected laterally and the subcutaneous tissue and scrotal fascia were incised to expose the outer covering layer of the testis (tunica vaginalis). The testis was then carefully separated from the epididymis using the scalpel blade and thumb forceps.

\section{Gross Morphometric Parameters}

The gross morphometric parameters that were taken included:

Weights of the right and left testis: These were taken using a digital weighing balance (OHAUS $\left.{ }^{\circledR}\right)$.

Length, width and height of the right and left testis: The testis was placed on an X-Y axis while the length, width and height were taken using a measuring ruler.

Volume of testis: This was obtained using the following methods:

Water displacement method: Briefly, this was done by filling up a calibrated measuring cylinder $(1000 \mathrm{ml})$ to a known initial level with normal saline e.g. $500 \mathrm{ml}$ (reading the level at the base of the meniscus). Then the testis was gently dropped into the cylinder and the final level of normal saline within the cylinder was read e.g. $520 \mathrm{ml}$. The volume of normal saline displaced by the testis was calculated by deducting the final level from the initial level of normal saline (i.e. $520 \mathrm{ml}-500 \mathrm{ml}=20$ $\mathrm{ml})$. This represented the volume of the testis. This volume in $\mathrm{ml}$ was converted to $\mathrm{cm}^{3}$, since $1 \mathrm{ml}=1 \mathrm{~cm}^{3}$.

By using the prolate ellipsoid formula: This was calculated by multiplying length $\times$ width $\times$ height $\times 0.52$ (i.e. $\mathrm{L} \times \mathrm{W} \times \mathrm{H} \times 0.52$ ).

By using the prolate spheroid formular: This was calculated by multiplying length $\times$ width ${ }^{2} \times 0.52$ (i.e. $\mathrm{L} \times$ $\left.\mathrm{W}^{2} \times 0.52\right)$.

By using the Lambert formula: This was calculated by multiplying length $\times$ width $\times$ height $\times 0.71$ (i.e. $\mathrm{L} \times \mathrm{W} \times$ $\mathrm{H} \times 0.71)$.

\section{Histological Procedure}

This was carried out as described previously (Raji et al, 2012). Selected images were captured using Moticam 2.0 digital camera attached to a computer.

\section{Histomorphometry}

The histomorphometric parameters of the captured images were taken and analyzed using the Motic Images Plus (MIPlus). The parameters taken included seminiferous tubule diameter (STD), seminiferous luminal diameter (SLD) and germinal epithelial height (GEH). Ten measurements were taken per section for each parameter.

\section{Statistical Analysis}

The data obtained in this study were analyzed using Pearson Product Moment Correlation (PPMC) and Student t-test Analyses at 5\% level of significance using SPSS version 20.

\section{Results}

\section{Gross Morphology}

The gross morphological study of the West African Dwarf (WAD) buck testis revealed that it was ellipsoidal in shape, covered by tunica vaginalis (a serous membrane) and a finely arranged network of arteries and veins. Deep to the tunica vaginalis was a tough fibrous layer directly covering the testis called tunica albuginea. Each of the testes has an attached and a free border (constituting the cranial and the caudal aspects of the testis respectively); the medial and the lateral margins; and the ventral and dorsal surfaces. The attached border tapers cranially while the free border appeared rounded (Figure 1). On incision, the mediastinum testis appeared as a densely white longitudinal structure at the centre of the testis.

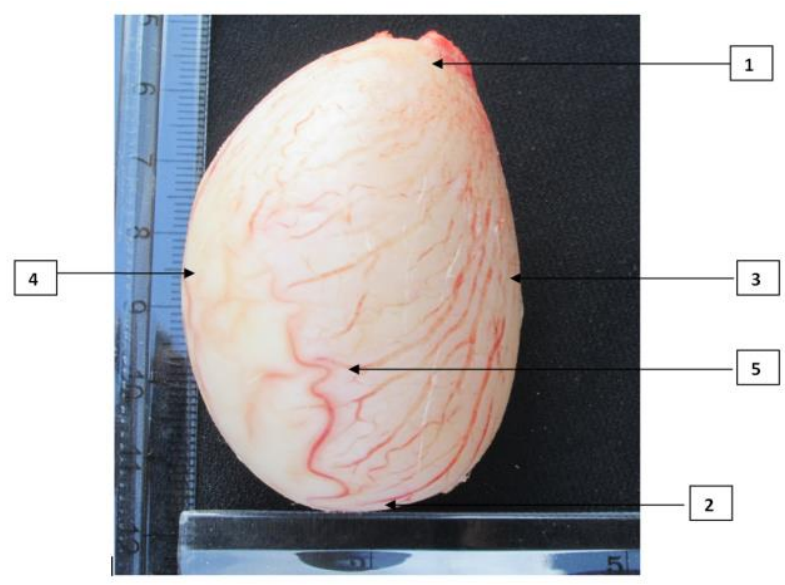

Figure 1 Shows testicular morphologic features of the left testis of the West African Dwarf buck; placed on X and Y axis for gross morphometric study

\section{Gross Morphometry}

Morphometric results revealed that the mean weight, length, height and width of the right testes were $28.6 \pm 0.5$ $\mathrm{g}, 6.0 \pm 0.1 \mathrm{~cm}, 2.6 \pm 0.0 \mathrm{~cm}$ and $3.6 \pm 0.1 \mathrm{~cm}$ respectively; and those of the left testes were $28.5 \pm 0.4 \mathrm{~g}$, $5.9 \pm 0.1 \mathrm{~cm}, 2.5 \pm 0.0 \mathrm{~cm}$ and $3.6 \pm 0.2 \mathrm{~cm}$ respectively. There were no significant differences in the means of these parameters between the right and left testes $(\mathrm{P}=0.99$, $0.92,0.88$ and 0.97 respectively at $\mathrm{P}<0.05)$. The mean volumes of the right and left testes using - the water displacement method were $28.60 \pm 0.50 \mathrm{~cm}^{3}$ and $28.50 \pm$ $0.47 \mathrm{~cm}^{3}$ respectively; the prolate ellipsoid formula were $28.7 \pm 1.28 \mathrm{~cm}^{3}$ and $28.4 \pm 1.35 \mathrm{~cm}^{3}$ respectively; the prolate spheroid formula were $38.96 \pm 1.57 \mathrm{~cm}^{3}$ and 36.74 $\pm 1.83 \mathrm{~cm}^{3}$ respectively; and the Lambert formula were $38.89 \pm 1.60 \mathrm{~cm}^{3}$ and $39.42 \pm 1.82 \mathrm{~cm}^{3}$ respectively. Comparing the water displacement method with the prolate ellipsoid formula, there were no significant 
differences between the means of the right testes $(\mathrm{P}=0.01)$ and left testes $(\mathrm{P}=0.01$. However, comparing the water displacement method with the prolate ellipsoid formula, there were significant differences between the means of the right testes $(\mathrm{P}=0.31)$ and the left testes $(\mathrm{P}=0.26)$; similarly when the water displacement method was compared with the Lambert formula $(\mathrm{P}=0.29$ and $\mathrm{P}=0.47)$ respectively. There was a strong correlation between the weight and volume (i.e. volume of water displaced) of the right and the left testes $(\mathrm{r}=0.97, \mathrm{P}=0.01$; and $\mathrm{r}=0.98$, $0.01, \mathrm{P}=0.01$ ) respectively).

\section{Histomorphology/ Histology}

Histology revealed that the WAD buck testis was divided into regularly arranged lobules by the tunica albuginea septae. Each lobule contained mostly rounded and some irregularly shaped seminiferous tubules (ST) (Figure 2). Each ST was lined by a basement membrane and a layer of germinal epithelium. The lumen of the ST was filled with sperm cells surrounded by an adluminal space. The germinal epithelia layer revealed two major categories of cells namely the proliferating population of spermatogonic cells and a non-proliferating sustentacular or sertoli cells. The sertoli cells appeared elongated with pale staining nuclei and were fewer in number (compared with the spermatogonic cells) but on a collective view, occupied most of the volume of the ST forming a bloodtestis barrier extending from the basal membrane into the lumen of the ST. The spermatogonic cells were arranged in successive concentric layers according to the level of maturity from the basal layer to the lumen of the ST. The earliest cells called the spermatogonia lied next to the basal layer and were small cells with dark oval nuclei. These were closely followed by the large cells with large round nuclei called spermatocytes which together with the sertoli cells formed the tight junctional complex referred to as the blood testis barrier. Above the spermatocytes were the spermatids which appeared as two generations of cells close to the lumen of the ST. The first generation of these cells appeared roundish with centrally located nucleus while the second generation was identified by their dark-blue heads and eosinophilic thin like flagella extending into the lumen (Figure 3). In between the adjacent ST were cells that appeared polyhedral and uninucleated called Leydig cells, occupying a considerable portion of the interstitial tissue (Figure 2).

\section{Histomorphometry}

The result for the Histomorphometric study is as presented on the Table 1. There were no significant differences between the right and left testes STD, SLD and $\mathrm{GEH}(\mathrm{P}=0.89,0.82$ and 0.86 respectively).

\section{Discussion}

In this study, we observed that the gross morphological characteristics of the WAD buck testis were similar to those previously reported in Indian buck goats (Nimase et al, 2008; Mohammed et al, 2011; Archana et al, 2014). This suggests that there are no distinct testicular morphological variations amongst these breeds of goats.

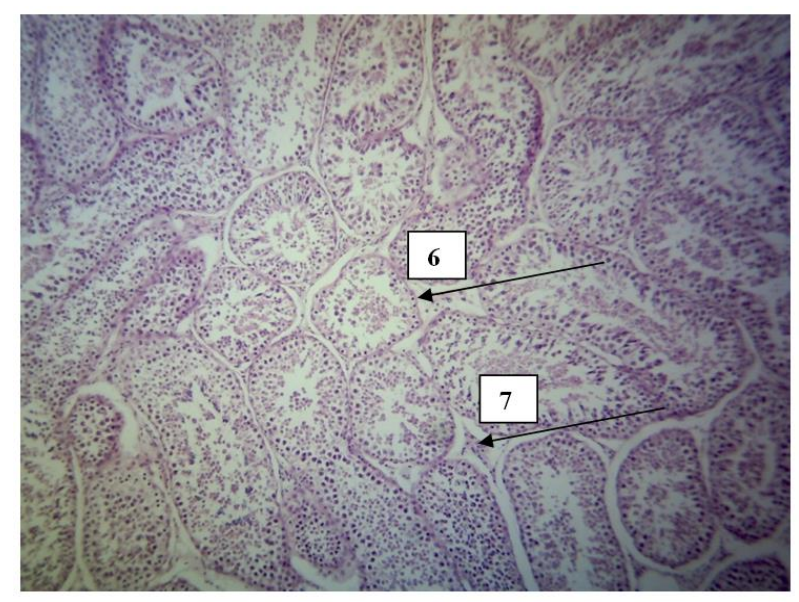

Figure 2 Shows the West African Dwarf buck testis seminferous tubules of various shapes and leydig cells lying in between adjacent seminiferous tubules, $H \& E \times 100$.

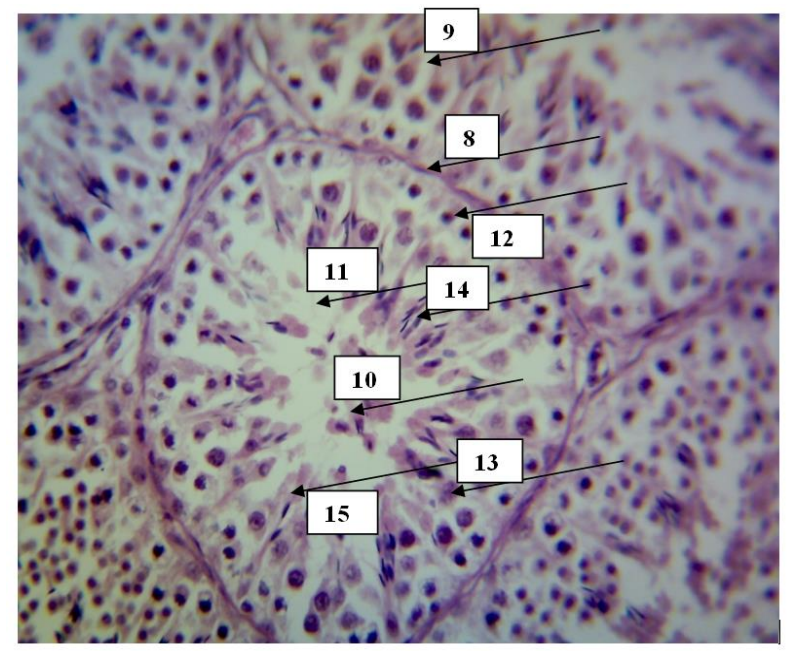

Figure 3 Shows the seminiferous tubules of the West African Dwarf buck with sperm filled lumen and germinal epithelia layer made up of different types of spermatogenic cells.

Table 1 Histomorphometry of the testes of post pubertal West African Dwarf bucks

\begin{tabular}{l|ccc}
\hline Parameters & $\mathrm{N}$ & $\begin{array}{c}\text { Right testis } \\
(\mu \mathrm{m})\end{array}$ & $\begin{array}{c}\text { Left testis } \\
(\mu \mathrm{m})\end{array}$ \\
\hline $\begin{array}{l}\text { Seminiferous tubular } \\
\text { diameter }\end{array}$ & 24 & $578.2 \pm 27.8$ & $569.4 \pm 26.1$ \\
$\begin{array}{l}\text { Seminiferous luminal } \\
\text { diameter }\end{array}$ & 24 & $258.0 \pm 29.6$ & $263.7 \pm 30.2$ \\
$\begin{array}{l}\text { Germinal epithelial } \\
\text { height }\end{array}$ & 24 & $194.9 \pm 28.8$ & $198.6 \pm 27.2$ \\
\hline
\end{tabular}

$\mathrm{N}$ : number of bucks. Data were expressed in mean \pm standard deviation; $\mathrm{P}<0.05$ level of significance.

Gross morphometric results revealed that there were no significant differences in the weight, length, height and width of the right and left testes. These findings are similar to those reported by Bitto and Egbunike (2006) and Ugwu (2009) with the exception of the testicular height taken in this study which was not documented by these previous Authors. From this additional parameter 
we took, we were able to calculate the volume of each testis from the three different formulae (as described above). Of these formulae, the volumes of testes calculated from the prolate ellipsoid formula was the closest to the volumes obtained using the water displacement method. We suggest that this formula is the best of the three in calculating the volume of the testis of WAD buck goats. As far as we know, this is a new approach in calculating testicular volume in this valuable breed of goat. However, in contrast, the Lambert formula has been reported to be the best for calculating testicular volume in human (Sakamoto et al, 2007; Sotos and Tokar, 2012). Further studies should be conducted to determine the best formula that would be most suitable for calculating testicular volume in other breeds of goats and species of animals and/or Veterinary practice. As regards using the water displacement method, we also observed that, the weight of the WAD buck testis was approximately the volume of normal saline (water) it displaced (constituting its own volume). This implies that the heavier the testis, the more the volume of water it displaces, hence the higher its volume. Since testicular volume is an index of spermatogenesis (Sakamoto et al., 2008), this implies that the heavier the weight of the testis, the more the seminiferous tubules the testis contains, hence the more spermatozoa it will produce.

The histomorphologic findings in this study were similar to those reported by Bordooi and Dhingra (1990) in Indian black beatle goats; Mohammed et al, (2011) in Iraqi indigenous goats; Olukole et al, (2014) in African sideneck turtle; Olukole and Obayemi (2010) in African great cane rats; and Awobajo et al, (2010) in Wistar strain albino rat.

However, the histomorphometric findings of this study are new as far as we know. Data on STD, SLD and GEH in WAD buck goats are very scarce. However, the mean STD we observed for the right and left testes (578.2 $\pm 27.8 \mu \mathrm{m}$ and $569.4 \pm 26.1 \mu \mathrm{m}$ respectively) were higher than those reported in pubertal and post pubertal Indian indigenous Gaddi buck goats $(202.55 \pm 4.49 \mu \mathrm{m}$ and $263.52 \pm 5.22 \mu \mathrm{m}$ respectively) by Archana et al, (2014); in Lori goats $(197.20 \pm 1.80 \mu \mathrm{m})$ by Mohammadzadeh et al, (2013) and in Alpine buck goats $(237 \pm 3.0 \mu \mathrm{m})$ by Leal et al, (2004). Also, the mean GEH we observed $(194.9 \pm 28.8 \mu \mathrm{m}$ and $198.6 \pm 27.2 \mu \mathrm{m}$ respectively) were higher than those reported in the Lori goat (39.2 \pm 0.98 $\mu \mathrm{m})$ by Mohammadzadeh et al, (2013) and in the Alpine bucks $(78 \pm 2.0 \mu \mathrm{m})$ by Leal et al, (2004). These differences may be due to breed variation. However, relating these with previous documentations that spermatogenic activities within the seminiferous tubules is a function of GEH; the higher the GEH, the more active the seminiferous tubule (in terms of spermatogenesis) and vice-versa (Castro et al, 2002; Shittu et al, 2008); the findings of this present study, suggest high spermatogenic activities in the seminiferous tubules of the WAD buck goat.

In this study, the morphological and morphometric characteristics of the WAD buck testis were highlighted. These will be useful in comparative regional anatomy and researches on the testis of these valuable breed of goats.

\section{References}

Archana P, Katiyar RS, Sharma DN, Farooqui MM, Prakash A. 2014. Postnatal Development of Testis in Gaddi Goat (Capra hircus). Int. J. Morphol., 32: 166-176.

Awobajo FO, Raji Y, Akinloye AK. 2010. Histomorphometric Changes in the Testes and Epididymis of Wistar Strain Albino Rats Following Fourteen Days Oral Administration of Therapeutic Doses of Some Antibiotics. Int. J. Morphol. 28: 1281-1287.

Bitto II, Egbunike GN. 2006. Seasonal Variations in the Morphometric Characteristics of the Pubertal West African Dwarf Buck in its Native Tropical Environment. Int. J. Morphol., 24:637-642.

Bordooi CC, Dhingra LD. 1990. Seasonal studies on the histomorphological status of the seminiferous epithelium of Indian Black Beatle goats, Indian J. Vet. Anat., 2: 1-7.

Castro ASC, Berndtson WE, Cardoso FM. 2002. Plasma and testicular testosterone levels, volume density and number of Leydig cells and spermatogenic efficiency of rabbits. Braz. Med. Biol. Res., 35: 493-498.

Daramola JO, Adeloye AA, Fatoba TA, Soladoye AO. 2007. Induction of puberty in West African Dwarf Buck-kids with exogenous Melatonin. Liv. Res. Rur. Dev., 19: 9-14.

Devendra C. 1999. Goats: Challenges for increased productivity and improved livelihoods. Outl. on Agric. 28: 215-226.

Gofur MR. 2015. Anatomy and histomorphometry of accessory reproductive glands of the Black Bengal buck. Eur. J. Anat., 19: 171-178.

Igbokwe IO, Grema HA, Ikpo AE, Mshelbwala FM, Igbokwe NA. 2009. Unilateral Crytorchidism in Nigerian Sahel Bucks. Int. J. Morphol., 27: 805-810.

Leal MC, Becker- Silva SC, Chiarini-Garcia H, Franca LR. 2004. Sertoli cell efficiency and daily spermproduction in goats (Capra hircus). Anim. Reprod. 1: 122-128.

Memon MA, Mickelsen WD, Goyal HO, 2007. Examination of the reproductive tract and evaluation of potential breeding soundness in the buck. In: Youngquist RS, Threlfall WR, editors, Current Therapy in Large Animal Theriogenology, 2nd ed. Saunders Elsevier, St Louis, MO, pp 515-518.

Mohammed AS, Kadium DA, Ebed AK, 2011. Some morphometric and histological description of the seminiferous, striaghted and rete testis tubules in the testis of indogenous male goats (two years old). Kufa J. Vet. Med. Sci., 2: 19-29.

Mohammadzadeh S, Abasi M, Tavafi M, Kiani A. 2013. Reproductive efficiency of an Indigenous Iranian goat (Capra hircus). Anim. Res. Int. 10: 1723-1729.

Nimase RG, Bhosle NS, Desale RJ, Deokar DK. 2008. Developmental histomorphology of testes in goat. Asian J. of Anim. Sci., 3: 116-119.

Okere C, Bradley P, Bridges ER, Bolden-Tiller O, Ford D, Paden A. 2011. Relationships among body conformation, testicular Traits and semen output in electro-ejaculate Pubertal kiko goat bucks. ARPN J. Agric. Bio. Sci., 6: 43-48.

Olukole SG, Obayemi TE. 2010. Histomorphometry of the Testes and Epididymis in the Domesticated Adult African Great Cane Rat (Thryonomys swinderianus). Int. J. Morphol., 24: 12511254.

Olukole SG, Oyeyemi MO, Oke BO. 2014. Biometrical and histometrical observations on the testis and epididymis of the African sideneck turtle (Pelusios castaneus). Eur. J. Anat. 18: 102-108.

Ozegbe PC. 2012. Immunohistochemical localization of the cytoskeletal proteins in the Abdominal and scrotal testes of mature and immature naturally unilateral cryptorchid West African Dwarf goats. Eur. J. Anat., 16: 104-112.

Raji LO, Fayemi OE, Ameen SA, Jagun AT. 2012. The effects of aqueous extract of Allium sativum (garlic) on some aspects of reproduction in the female albino rat wister strain). Glo. Vet., 8: 414-20. 
Ridler AL, Smith SL, West DM, 2012. Ram and buck management. Anim. Reprod. Sci. 130:180-183.

Sakamoto H, Saito K, Oohta M, Inoue K, Ogawa Y, Yoshida H. 2007. Testicular Volume Measurement: Comparison of Ultrasonography,Orchidometry, and Water Displacement. Urology 69: 152-157.

Sakamoto H, Ogawa Y, Yoshida H. 2008. Relationship between testicular volume and testicular function: Comparison of the Prader orchidometric andultrasonographic measurements in patients with infertility. Asian J. Androl. 10: 319-324.
Shittu LAJ, Shittu RK, Osinubi AA, Ashiru OA. 2008. Stereological evidences of Epithelial Hypoplasia of seminiferous tubules induced by Mesterolone in adult Sprague-dawley rats. Afric. J. Endocr. Met. 7: 14-17.

Sotos JF, Tokar NJ. 2012. Testicular volumes revisited: A proposal for a simple clinical method that can closely match the volumes obtained by ultrasound and its clinical application. Int. J. Ped. Endocr., 17: 1-11.

Ugwu SOC. 2009. Relation between SC in-situ testicular measurements and sperm reserves in the WAD bucks. Afric. J. of Biotech. 8: 1354-1357. 